\title{
Letters
}

\section{Serotonin nerve cells in Alzheimer's disease}

Sir: A recent report ${ }^{1}$ showing that the uptake of serotonin (5HT) by neocortical biopsy tissues is significantly reduced in patients with Alzheimer's disease (AD) implies that there may also be damage to the 5HT-containing nerve cells; situated in the raphe nuclei of the brain stem and mid brain, ${ }^{2}$ in this condition. We have examined those nerve cells which lie in the caudal part of the mesencephalon and upon the medial and dorsal surfaces of the medial longitudinal fasciculus, and which are variously known as the nucleus supratrochlearis, ${ }^{3}$ or dorsal tegmental nucleus (DTN). ${ }^{4}$ These together with neurons of the nucleus dorsalis raphe and nucleus centralis superior make up the 5HTcontaining nerve cells of the upper brain stem. Changes in their structure are sought and capacity for function is assessed by measurement of nucleolar volume and cytoplasmic RNA content. ${ }^{6}$

Brains were obtained at necropsy from 15 histologically confirmed cases of AD (age $77.4 \pm 1.8$ years; postmortem delay $35.4 \pm 6.5$ hours) and nine controls of similar age (79.6 \pm 1.2 years; postmortem delay 36.9 \pm 3.7 hours) dying without neurological or psychiatric disease and judged to be mentally preserved. Immediate cause of death was similar in both groups, being associated with bronchopneumonia or cardiac insufficiency. Paraffin sections cut at a thickness of $16 \mu \mathrm{m}$ from blocks of pons (at level of nucleus of IV cranial nerve) were stained for RNA. ${ }^{6}$ Nucleolar volume and cytoplasmic RNA content were measured ${ }^{5}$ in 30 cells of the medial and lateral divisions of $\mathrm{DTN}^{2} 3$ in all 24 cases. In most of the patients with AD globose neurofibrillary tangles occupying much of the nerve cell perikaryon were common (fig) in both divisions, though senile plaques were not seen. The table shows that, when compared with controls, nucleolar volume and cytoplasmic RNA content are significantly reduced ( $p<0.001$ in each instance) in AD, by 31 and $38 \%$ respectively, in both medial and lateral divisions of DTN. The changes in cell structure (tangle formation) together with a reduced functional capacity probably form the basis for the altered 5HT metabolism, reported at necropsy, ${ }^{7}$ or within the living patient, ${ }^{189}$ with AD.

The impaired functioning, in $\mathrm{AD}$, of

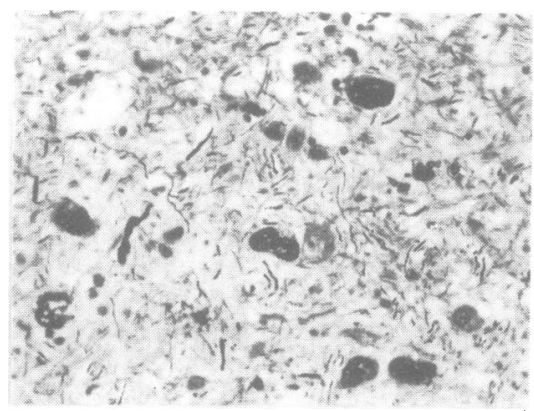

Fig. Section of dorsal tegmental nucleus (see text).

Table Nucleolar volume and cytoplasmic RNA content of nerve cells of dorsal tegmental nucleus in Alzheimer's disease patients and controls

\begin{tabular}{|c|c|c|}
\hline & \multicolumn{2}{|c|}{ Nucleolar volume $\left(\mu^{3}\right)$} \\
\hline & Medial DTN & Lateral DTN \\
\hline $\begin{array}{l}\text { Alzheimer's } \\
\text { disease } \\
(n=15)\end{array}$ & $22 \cdot 9 \pm 1 \cdot 0^{*}$ & $23.0 \pm 1 \cdot 0^{*}$ \\
\hline \multirow[t]{3}{*}{ Controls $(\mathrm{n}=$} & $33.2 \pm 0.9$ & $33 \cdot 2 \pm 0 \cdot 9$ \\
\hline & \multicolumn{2}{|c|}{$R N A$ content $(A U)$} \\
\hline & Medial DTN & Lateral DTN \\
\hline $\begin{array}{l}\text { Alzheimer's } \\
\text { disease } \\
(\mathrm{n}=15)\end{array}$ & $20.9 \pm 0.8^{*}$ & $21 \cdot 0 \pm 0.7^{*}$ \\
\hline Controls $(\mathrm{n}=$ & $33 \cdot 7 \pm 1 \cdot 1$ & $34 \cdot 1 \pm 0 \cdot 8$ \\
\hline
\end{tabular}

$\mathrm{AU}=$ arbitrary units

${ }^{*} p$ at least $<0.001$ from control value (Student $t$ test)

other groups of neurons, such as the cholinergic cells of the basal forebrain (substantia innominata) ${ }^{10} 11$ and the noradrenergic cells of the locus caeruleus, ${ }^{12-14}$ which also give rise to pathways projecting to the neocortex, indicates that the changes in 5HT neurons, may therefore be yet another aspect of a widespread process of deprivation of cortical input. Furthermore, these additionally damaged serotinergic and noradrenergic systems may be part of the reason as to why those therapeutic measures aimed at restituting the cholinergic system alone, have met with only limited success.

DAVID MA MANN

PETER O YATES

Department of Pathology

The University

Manchester

M13 9PT, UK

Accepted 29 October 1982

\section{References}

' Benton JS, Bowen DM, Allen SJ et al. Alzheimer's disease as a disorder of isoden- $\$$ dritic core. Lancet 1982;i:456.

${ }^{2}$ Ungerstedt U. Stereotaxic mapping of the monoamine pathways of the rat brain. Acta of Physiol Scand 1971;Suppl. 367:1-48.

${ }^{3}$ Olszewski J, Baxter D. Cytoarchitecture of the human brain stem. Basel, S. Karger, 1954. 요

${ }^{4}$ Ranson SW, Clark SL. The anatomy of the nervous system. 1947. London. WB Saunders.

${ }^{5}$ Carpenter MB. Human neuroanatomy 7th ed. $\frac{9}{\square}$ Baltimore. Williams and Wilkins, 1976.

- Mann DMA, Yates PO, Stamp JE. Relation- 믐 ship of lipofuscin pigment to ageing in the $\frac{\bar{S}}{\partial}$ human nervous system. J Neurol Sci 1978;35:83-93.

' Adolfsson R, Gottfries CG, Roos BE, Winblad ڤ B. Changes in brain catecholamines in patients with dementia of Alzheimer type. ? Br J Psychiat 1979;135:216-23.

8 Gottfries CG, Gottfries I, Roos BE. $\vec{\omega}$ Homovanillic acid and 5 hydroxyindole acetic acid in the cerebrospinal fluid of patients with senile dementia, presenile $\frac{7}{0}$ dementia and Parkinsonism. J Neurochem is 1969;16:1341-5.

argentiero V, Tavolato B. Dopamine (DA and serotonin levels in the cerebrospin fluid (CSF) in Alzheimer's presenile demerd tia, under basic conditions and aftê stimulation with cerebral cortex phoß pholipids. J Neurol 1980;224:53-8.

${ }^{10}$ Whitehouse PJ, Price DL, Clark AW, Coytk JT, DeLong M. Alzheimer disease: evg dence for selective loss of cholinergo neurones in the nucleus basalis. Ann Neuros 1981;10:122-6.

"Mann DMA, Yates PO. Is the loss of cerebr cortical CAT activity in Alzheimers disease $\omega$ due to degeneration of ascending cholinergic cells? J Neurol Neurosurg Psychiatry 1982;45:936.

${ }^{2}$ Mann DMA, Yates PO, Hawkes J. The noradrenergic system in Alzheimer and multiinfarct dementias. $J$ Neurol Neurosurg Psychiatry 1982;45:113-9.

${ }^{13}$ Tomlinson BE, Irving D, Blessed G. Cell loss in the locus caeruleus in senile dementia of Alzheimer type. $J$ Neurol Sci 1981;49:419-28.

${ }^{14}$ Bondareff W, Mountjoy CQ, Roth M. Loss of neurones of the origin of the adrenergic projection to cerebral cortex (nucleus locus caeruleus) in senile dementia. Neurology (NY) 1982;32:164-9.

Hereditary multiple exostoses with spinal cord compression

Sir: Multiple exostoses is a well-known disorder characterised by cartilaginous and bony protuberances most often involving $\Omega$ the metaphyseal regions of tubular long $N$ bone. A family history is present in 
approximately $60 \%$, the mode of inheritance being autosomal dominant with equal sex distribution. ' Neurological complications are uncommon and, when present, usually are due to pressure on peripheral nerves by the bony growths. Vertebral exostoses are found in less than $1 \%$ of patients, ${ }^{2}$ and only 26 cases with compression of the spinal cord have been recorded.

A 33-year-old man presented with spastic paraparesis. At least eight close relatives were known to have minor skeletal deformities. An older sister had undergone surgery, because of exostoses interfering with her right superficial peroneal nerve, giving rise to sensory disturbances. Since childhood the patient himself had noticed bony outswellings in several locations. Neurological symptoms had started 6 months prior to admission with a feeling of coldness and tingling numbness in the feet, slowly spreading to the whole of both lower extremities, accompanied by weakness and difficulty in walking. When first seen, examination revealed a spastic paraparesis with bilateral weakness, hyperactive tendon reflexes, ankle clonus and Babinski sign, but no sensory deficit. The following week there was a sudden increase of numbness and weakness. Urinary urgency was noted. Distal-sensation to touch and pin prick was lost from above the umbilicus, and abdominal reflexes disappeared. Laboratory tests, including examination of lumbar CSF, showed no abnormalities. Radiological examination confirmed the presence of exostoses in the extremities, but failed to demonstrate any in the spine. At myelography there was a total block at the level of T4, but no cause for this could be seén. Computed tomography was therefore performed. This showed (fig) a $3 \cdot 5 \mathrm{~cm}$ longhour glass shaped tumour of bony density on the left side, but occupying most of the spinal canal. After laminectomy from $T 2$ to $\mathrm{T} 4$ an exostoses was found originating from the T4 and displacing the spinal cord to the right. Microscopically the exercised tumour consisted of benign bone and cartilage. Postoperatively there was improvement. After 7 months gait, strength and sensation were essentially normal.

Including that of our own, records in the literature have been found of 26 cases of medullary compression by a vertebral exostoses. $^{2-23}$ In 13 instances there was a positive family history. Seventeen patients were males. All but three had exostoses of the peripheral skeleton, which had been noticed since early childhood. The patients were aged 7-58 years when diagnosis of spinal compression was made, but the great

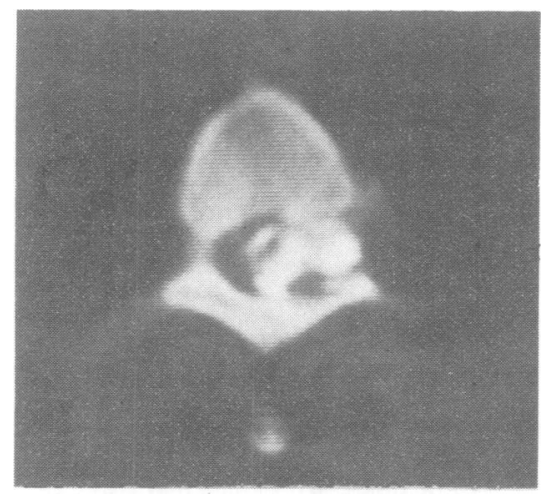

Figure CT scan through T4 showing hourglass shaped exostosis originating from the left and occupying the major part of the spinal canal.

majority were in their second to fourth decade with a mean age of 23 years. The oldest patient was exceptional in that she had experienced neurological symptoms for 32 years and was not improved by operation. ${ }^{3}$ Otherwise the duration of symptoms was very variable, the median time before diagnosis being approximately 1 year. The clinical picture has been that of an expanding intraspinal process, finally resulting in 12 parapareses ${ }^{2-11}$, five paraplegias $^{12-15}$, two quadripareses ${ }^{16} 17$ and one quadriplegia. ${ }^{18}$ Some lateralisation of neurological deficits was usual, and three cases have been described as hemipareses, ${ }^{19-21}$ one as an incomplete BrownSequard syndrome. ${ }^{22}$ All but one patient had sensory involvement. ${ }^{21}$ Pure sensory involvement was seen twice. ${ }^{43}$ In most cases the diagnosis as to dermatome level was possible on clinical grounds. On two occasions the exostosis was in the lumbar spine, the remainder being equally distributed between cervical and thoracic vertebrae. Most interesting is, that $\mathrm{C} 2$ was the site of origin in seven patients.

Myelography has been employed when possible and has been recommended to reveal the actual size of the tumour, ${ }^{4}$ since the cartilage cap over the bony exostosis is radiolucent. The usefulness of accurate tomography has also been stressed. ${ }^{45}$ In the present case myelgraphy produced insufficient information, but was valuable as guidance for the CT scan, which because of easy access was undertaken next. This investigation has only been carried out once before and was not found superior to careful tomography. ${ }^{5}$ In our case, however, CT scan provided all the preoperative information needed.
Three patients with exostosis of the $\mathrm{C} 2$ died without operation being performed. ${ }^{61623}$ The remainder underwent laminectomy and eventual excision of the tumour. One patient with a cervical exostosis and sudden onset of symptoms died shortly after operation with cardiorespiratory failure. ${ }^{17}$ One patient, as mentioned, was unchanged after surgery. ${ }^{3}$ Thus 21 were improved, and of these 11 are described in terms like "fully restituted" or "almost normal". The median duration of symptoms in this group of patients benefitting the most from neurosurgery seems to have been 6 months, which is in contrast to the estimated 1 year in the overall material.

In conclusion, when confronted with a patient with multiple exostosis suffering neurological symptoms, the possibility of spinal cord compression should be considered. The majority of these patients may be improved by surgical intervention. As there seems to be a relationship between duration of symptoms and postoperative recovery, early diagnosis is crucial.

T BUUR MM M $\varnothing \mathbf{R C}$ ڤै University Hospita: فे of Linköping 58185 Linköping@ి Swedev

References

' Solomon L. Hereditary multiple exostoses. Am J Hum Genet 1964;16:351-63.

${ }^{2}$ Gokay H, Bucy PC. Osteochondroma of the lumber spine: report of a case. J Neurosurg 1955; 12:72-78.

${ }^{3}$ Sam UH, Howard LL. Hereditary multiple exostoses with myelopathy. Arch Neurol 1979;36:714

${ }^{4}$ Palmer FJ, Blum PW. Osteochondroma with spinal cord compression: Report of three cases. J Neurosurg 1980;52:842-5.

${ }^{5}$ Ferrari G, Taddei L, Vivenza C, Rossi G Paraparesis in hereditary multiple exostoses: Case report. Neurology (Minneap) 1979;29:973-7.

- Ochsner EH, Rothstein T. Multiple exostoses including an exostosis within the spinal canal with surgical and neurological observations Ann Surg 1907;46:608-16.

' Cannon JF. Hereditary multiple exostosis. Am J Hum Genet 1954;6:419-25.

${ }^{8}$ Goncharova RF, Dogaeva MA, Koraidi LS. Spinal cord compression by exostoses.Vopr Neirokhir 1965;29:60.

' Decker RD, Wei WC. Thoracic cord compression from multiple hereditary exostoses associated with cerebellar astrocytoma: Case report. $J$ Neurosurg 1969;30:310-12.

${ }^{19}$ Goldenberg DB, Reinhoff WF, Rao PS Osteochondroma with spinal cord 
compression: Report of a case. J Can Assoc Radiol 1968;19:192-4.

" Urso S, Carfagni A, Amorese V. Vertebral compression syndrome in multiple exostoses. Ital J Orth Traumatol 1977;3:333-40.

12 Petit-Dutaillis D, Lereboullet J. Paraplégie par fibrochondrome des vertebres dorsales supérieures ches une malade atteinte de maladie ostéogénique. Bull Soc Chir Paris 1934;60:694-6.

${ }^{13}$ Larson NE, Dodge HW, Rushton JG, Dahlin DC. Hereditary multiple exostoses with compression of the spinal cord. Proc Staff Meet Mayo Clin 1957;32:728-34.

${ }^{14}$ Adam H, Morin P. Compression medulaere par eostose au cours d'une maladie exostosante. Press Med 1966;74:660.

${ }^{15}$ Signargout J, Guegan Y, Lemare B, Simon J. Les paraplégies de la maladie des exostoses multiple. J Radiol Electrol Med Nucl 1973;54:403-7.

${ }^{16}$ Chiurco AA. Multiple exostoses of bone with fatal spinal cord compression. Neurology (Minneap) 1970;20:275-8.

${ }^{17}$ Singh DS, Rao SS, Sharma S, Srivastava KK, Yadav SS. Cervical cord compression from multiple hereditary exostoses. J Asso Phys Ind 1980;28:5335-7.

${ }^{18}$ Oberndorf CP. A case of multiple exostoses coupled with syringomyeli. NY Med J 1910;91:479-83.

${ }^{19}$ Carmel PW, Crammer FJ. Cervical cord compression due to exostoses in a patient with hereditary multiple exostoses. J Neurosurg 1968;28:500-3.

${ }^{20}$ Vinstein AL, Franken EA. Hereditary multiple exostoses: report of a case with spinal cord compression. Am J Roentgenol Radium Ther Nucl Med 1971;112:405-7.

${ }^{21}$ Madigan R, Worral T, McClain E. Cervical cord compression in hereditary multiple exostoses. J Bone Joint Surg 1974;56A:401-4.

${ }^{22}$ Slepian A, Hamby WB. Neurological complications associated with hereditary deforming chondrodysplasia: Review of the literature and a report on two cases occurring in the same family. J Neurosurg 1951;8:52935.

${ }^{23}$ Reid J. A case of disease of the spinal cord from an exostosis of the second cervical vertebra. Mon J Med Science 1843;3:194-8. As cited by Madigan et al.

\section{Alcaptonuria with Seizures}

Sir: Alcaptonuria, an inherited metabolic disorder of tyrosine metabolism presents in childhood without any symptoms other than the complaint of darkening of urine on standing. We wish to report the occurrence of seizures in one of our cases of alcaptonuria.

An 8-year-old school boy (A) with normal birth history and normal developmental milestones presented with occasional seizures. The first fits of generalised tonicclonic type occurred on the 4th day of life and thereafter attacks occurred approximately once a year. A casual mention was made by his parents that his urine became dark on standing and his undergarments were stained, so alcaptonuria was suspected. There were no symptoms of joint pain or back-ache. His intelligence was normal. Neurological examination revealed no abnormality and clinical, radiological and ECG examination of the heart were non-contributory. On enquiring into the family history, it was found that he had four sisters and a brother. His 23 year-old eldest sister (AL) had also a similar darkening of her urine on standing, and darkish triangular pigmentation was seen in the sclerae of her eyes. Neither she nor the other sibs had convulsions or joint pains.

Routine investigations, including total and differential WBC counts, haemoglobin content, ESR, blood sugar, urea and cholesterol were normal in both $\mathrm{A}$ and $\mathrm{AL}$. CT head scan revealed no abnormality in A. The urine of both the sibs showed no albumin, sugar or deposits on preliminary examination but did turn darkish brown on standing. The presence of homogentisic acid in the urine of $A$ and $A L$ was proved by paper chromatography. The EEG in both cases showed evidence for epileptic activity. There were clear-cut bilaterally synchronous 3 to $3 \frac{1}{2} \mathrm{~Hz}$ high voltage slow wave bursts appearing rhythmically, with independent discrete and synchronous spike discharges over both hemispheres in the EEG of the boy; the EEG of the asymptomatic sister also showed evidence of epileptic activity in the form of bilaterally synchronous spike discharges. The EEGs of the other sibs were normal.

The presence of alcaptonuria and seizures in the two cases described may be a fortuitous coexistence. However, only the two sibs (out of the six) who had alcaptonuria had epileptic discharges on the EEG, with one of them (A) also manifesting overt convulsions. No one else suffered from seizures in the family and the EEGs of the sibs with no alcaptonuria were normal. The association of seizures with certain types of disordered amino acid metabolism is well known. The commonest situation is probably phenylketonuria, where EEG changes have been studied in detail. ${ }^{1}$ It is hypothesised that damage to the brain occurs very early in life when the immature brain is presented with abnormal patterns of amino acids from which it cannot construct its essential and permanent components. ${ }^{2}$ Cases of alcaptonuria picked up occasionally nowadays are not reported in the literature unless some remarkable or strange clinical features are present. In addition to the well known scleral pigmentation and ochronotic arthropathy that are the hallmarks of the full classical clinical presentation, a few rare features also have been reported. They include heart disease, ${ }^{34}$ prostatitis, ${ }^{5}$ renal stones, ${ }^{6}$ and "nephrosis". ' So far, no case of alcaptonuria has been described with seizures; and this prompted us to report this association of alcaptonuria with seizures although the exact mechanism remains unclear.

PA BHASKAR, B NEELAKANDAN Department of Neurology, Thanjavur Medical College Hospital, Thanjavur, India.

\section{References}

' Gross PT, Berlow S, Schuett UE, Farriello RG. EEG in phenylketonuria. Arch Neurol 1981;38:122-6.

${ }^{2}$ Knox WE. Pathogenetic effects of elevated plasma phenylalamine in phenylketonuria. In: Folch-Pi J, ed. Chemical Pathology of the Nervous System. New York: Pergamoro on Press, 1961;32.

${ }^{3}$ Smith HP, Smith HP, Jr. Ochronosis: report of two cases. Ann Intern Med 1955;42:171. @

${ }^{4}$ Lichenstein L, Kaplan L.Hereditary ochronosis $\sigma$ pathological changes observed in two necropsied cases. Am J Pathol 1954;30:99.

${ }^{5}$ Cooper PA. Alcaptonuria with ochronosis. Pro $R$ Soc Med 1951;44:917.

- Young HH. Calculi of the prostate associate with ochronosis and alcaptonuria. J Uro $\vec{b}$ 1944;51:48.

Cooper JA, Moran TJ. Studies on ochronosis. AMA Arch Path 1957;64:46. 